\title{
Postępy w diagnostyce i leczeniu chorych na chłoniaki nie-Hodgkina
}

\author{
Advances in the diagnosis and treatment of patients \\ with non-Hodgkin lymphomas
}

\author{
Ewa Lech-Marańda ${ }^{1,2}$, Ewa Kalinka-Warzocha ${ }^{3}$, Krzysztof Warzocha ${ }^{1}$ \\ ${ }^{1}$ Klinika Hematologii, Instytut Hematologii i Transfuzjologii, Warszawa \\ ${ }^{2}$ Klinika Hematologii i Transfuzjologii, Centrum Medyczne Kształcenia Podyplomowego, Warszawa \\ ${ }^{3}$ Oddział Chemioterapii, Wojewódzki Szpital Specjalistyczny im. M. Kopernika, Łódź
}

\begin{abstract}
Streszczenie
$W$ pracy przedstawiono najważniejsze osiagnięcia zwiazane $z$ diagnostyka $i$ leczeniem chorych na chtoniaki nie-Hodgkina, w szczególności chtoniaka grudkowego, makroglobulinemie Waldenströma, chtoniaka $z$ komórek płaszcza, chtoniaki rozlane $z$ duzych komórek $B$, pierwotnego chtoniaka śródpiersia $z$ dużych komórek B oraz chtoniaki $z$ obwodowych komórek T. Kryterium wyboru omawianych zagadnień byt ich wplyw na poprawe wczesnych i odlegtych wyników leczenia.

Słowa kluczowe: chłoniak grudkowy, makroglobulinemia Waldenströma, chłoniak z komórek płaszcza, chłoniaki rozlane $z$ dużych komórek B, pierwotny chłoniak śródpiersia z dużych komórek B, chłoniaki z obwodowych komórek T
\end{abstract}

Hematologia 2015; 6, 1: 31-43

\begin{abstract}
This paper discusses the vital advances made for patient diagnosis and treatment of non-Hodgkin lymphomas, which in particular includes follicular lymphoma, Waldenström macroglobulinaemia, mantle cell lymphoma, diffuse large B-cell lymphoma, primary mediastinal large B-cell lymphoma and peripheral T-cell lymphoma. Recent studies demonstrating key improvements in early and long-lasting therapy were specially considered.
\end{abstract}

Key words: follicular lymphoma, Waldenström macroglobulinemia, mantle cell lymphoma, diffuse large B-cell lymphoma, primary mediastinal large B-cell lymphoma, peripheral T-cell lymphoma

Hematologia 2015; 6, 1: 31-43

\section{Wprowadzenie}

Chłoniaki nie-Hodgkina (NHL, non-Hodgkin lymphoma) stanowią bardzo heterogenną grupę nowotworów, co znalazło odzwierciedlenie w opublikowanej w 2008 roku klasyfikacji Światowej Organizacji Zdrowia (WHO, World Health Orga- nization). W ostatnich latach dokonał się znaczny postęp zarówno w zrozumieniu patogenezy tych nowotworów, jak i zastosowaniu nowych metod ich leczenia. W niniejszej pracy przedstawiono najważniejsze osiągnięcia dotyczące NHL z ostatnich lat, które miały największy wpływ na wczesne i odległe wyniki leczenia chorych. 


\section{Chłoniak grudkowy}

U chorych na chłoniaka gudkowego (FL, follicular lymphoma) w stadium I i II (bez bulky tumor) według zmodyfikowanej w Lugano klasyfikacji z Ann Arbor, w przeciwieństwie do stadiów zaawansowanych, należy podjąć próbę radykalnej terapii. Postępowaniem rekomendowanym przez większość badaczy, w tym National Comprehensive Cancer Network (NCCN), jest radykalna radioterapia obszarów pierwotnie zajętych (IF-RT, involved-field radiotherapy) w dawce 24-30 Gy. W codziennej praktyce klinicznej alternatywną opcją wobec IF-RT jest immunochemioterapia $z$ IF-RT lub bez niej. W 2012 roku Friedberg i wsp. [1] opublikowali wyniki leczenia chorych na FL w stadium ograniczonym zgłaszanych do amerykańskiego rejestru (National LymphoCare Study) w latach 2005-2007. Łącznie zgłoszono 471 chorych w stadium I, ale tylko u 206 pacjentów, u których przeprowadzono bardzo precyzyjną ocenę zaawansowania klinicznego $z$ mielogramem i trepanobiopsją szpiku oraz metodami tomografii komputerowej i/lub pozytonowej tomografii emusyjnej (PET, positron emission tomography) całego ciała, potwierdzono rzeczywiście stadium I. Wykazano, że spośród 206 chorych w stadium I immunochemioterapie $\mathrm{z}$ zastosowaniem rytuksymabu otrzymało $28 \%$, radioterapię $-27 \%$, immunochemioterapię oraz radioterapię - 13\%, u $17 \%$ zastosowano strategię watch and wait, $12 \%$ chorych leczono monoterapią rytuksymabem, a u 3\% stosowano inne formy leczenia. Przy 57-miesięcznej medianie obserwacji statystycznie dłuższe przeżycie wolne od progresji (PFS, progression-free survival) stwierdzono u chorych leczonych immunochemioterapią (współczynnik ryzyka [HR, hazard ratio] $=0,36$, 95-proc. przedział ufności [CI, confidence interval] $0,16-0,82)$ lub immunochemioterapią w połączeniu $z$ radioterapią $(H R=0,11,95 \%$ CI $0,01-0,83)$ w porównaniu $z$ chorymi poddanymi samej radioterapii. Nie obserwowano natomiast różnic w zakresie przeżycia całkowitego (OS, overall survival) po porównaniu wyżej wymienionych grup chorych. Wnioski z powyższego badania powinny być takie, że dopóki w prospektywnych, randomizowanych badaniach nie zostanie wykazana przewaga immunochemioterapii nad IF-RT, dopóty u pacjentów $z$ ograniczoną postacią FL należy, zgodnie $z$ obowiązującymi rekomendacjami, stosować IF-RT.

Chorzy na zaawansowanego FL (stadium II bulky oraz III-IV wg zmodyfikowanej w Lugano klasyfikacji z Ann Arbor) powinni być leczeni wtedy, gdy są spełnione kryteria GELF (Group d'Etude des Lymphomes Folliculaires) lub BNL (British National Lymphoma). Wybór immunochemioterapii I linii przez wiele lat pozostawał kontrowersyjny. Pierwsze prospektywne, randomizowane badanie służące porównaniu leczenia indukującego według schematów R-CVP (rytuksymab, cyklofosfamid, winkrystyna, prednizon), R-CHOP (rytuksymab, cyklofosfamid, doksorubicyna, winkrystyna, prednizon) i R-FM (rytuksymab, fludarabina, mitoksantron) opublikowano w 2013 roku [2]. Pięćset trzydziestu czterech pacjentów w zaawansowanym stadium FL poddano randomizacji do leczenia według powyższych schematów. Łączny odsetek odpowiedzi (ORR, overall response rate) wyniósł $88 \%, 93 \%$ i $91 \%$, odpowiednio, u chorych leczonych według schematu R-CVP, R-CHOP i R-FM $(p=0,247)$. Przy 34-miesięcznej medianie obserwacji szacowane 3-letnie PFS wynosiło odpowiednio $52 \%, 68 \%$ i $63 \%(\mathrm{p}=0,011)$, a 3-letnie OS było takie samo w trzech grupach chorych i wynosiło 95\%. Neutropenię III-IV stopnia według WHO obserwowano statystycznie częściej u chorych leczonych R-FM (64\%) w porównaniu z pacjentami otrzymującymi R-CVP (28\%) lub R-CHOP (50\%; $\mathrm{p}<0,001)$. Małopłytkowość III-IV stopnia według WHO odnotowywano częściej u chorych leczonych R-CHOP (3\%) lub R-FM (8\%) niz R-CVP (0\%; $\mathrm{p}<0,001)$. Nie wykazano statystycznej różnicy w zakresie częstości występowania infekcji III-IV stopnia według WHO między poszczególnymi grupami chorych. Biorąc pod uwagę wydłużenie PFS i toksyczność leczenia, immunochemioterapia R-CHOP wydaje się przeważać nad pozostałymi schematami. Przy wyborze leczenia indukującego zawsze należy ocenić indywidulane ryzyko u chorego i wziąć pod uwagę wczesną i późną kardiotoksyczność antracyklin oraz obecność w wywiadzie lekarskim chorób układu sercowo-naczyniowego.

Pewne nadzieje na poprawę skuteczności leczenia indukującego dały wyniki prospektywnego, wieloośrodkowego, randomizowanego badania, w którym porównano schemat R-B (rytuksymab, bendamustyna) $\mathrm{z}$ R-CHOP u chorych na chłoniaki powolne i chłoniaka $z$ komórek płaszcza (MCL, mantle cell lymphoma) [3]. Do badania włączono 549 chorych, w tym 274 trafiło losowo do grupy leczonej R-B, a 275 - do grupy leczonej R-CHOP. $\mathrm{W}$ obu grupach ponad $50 \%$ chorych stanowili pacjenci z FL w III lub IV stadium zaawansowania według klasyfikacji z Ann Arbor. Pierwszorzędowym punktem końcowym badania była ocena PFS i wykazanie, że chorych leczonych R-B nie cechuje krótszy o więcej niż 10\% PFS w porównaniu $z$ pacjentami leczonymi R-CHOP (badanie 
non-inferiority). Przy 45-miesięcznej medianie obserwacji u 279 chorych na FL mediana PFS w grupie leczonej R-B nie została jeszcze osiagnięta, a w grupie leczonej R-CHOP wynosiła 40,9 miesiąca $(\mathrm{p}=0,0072)$. Nie było statystycznych różnic w zakresie OS między obiema grupami, a mediana OS w żadnej $z$ nich nie została jeszcze osiągnięta. Schemat R-B był lepiej tolerowany przez chorych niz R-CHOP - statystycznie rzadziej obserwowano toksyczność hematologiczną ( $\mathrm{p}<0,0001)$, infekcje $(\mathrm{p}=0,0025)$, obwodowe neuropatie $(\mathrm{p}<0,0001)$, zapalenie jamy ustnej $(\mathrm{p}<0,0001)$ oraz łysienie $(\mathrm{p}<0,0001) . Z$ kolei w grupie leczonej R-B częściej występowały skórne reakcje nadwrażliwości i rumień niż w grupie leczonej R-CHOP ( $=0,024)$. Wydaje się więc, $\dot{z} e$ schemat R-B mógłby zastąpić bardziej toksyczne leczenie R-CHOP, ale obecnie bendamustyna nie jest jeszcze zarejestrowana w I linii leczenia u chorych na NHL o powolnym przebiegu klinicznym i nie jest w tym wskazaniu w Polsce refundowana.

Rolę radioimmunoterapii jako leczenia konsolidującego podsumowano w badaniu Morschhausera i wsp. [4] wynikami długoletniej obserwacji (mediana 7,3 roku) chorych leczonych w międzynarodowym, randomizowanym badaniu FIT (First Line Indolent). Czterystu dziewięciu chorych na FL w stadium II-IV, którzy uzyskali całkowitą odpowiedź (CR, complete response), niepotwierdzoną CR (CRu, CR unconfirmed) lub częściową odpowiedź (PR, partial response) po leczeniu I linii, byli poddani randomizacji do leczenia konsolidującego ibritumomabem tiuksetanem znakowanym radioaktywnym itrem-90 ( ${ }^{90}$ Y-ibritumomab) lub do obserwacji. Radioimmunoterapię stosowano w następującym schemacie: rytuksymab w dawce $250 \mathrm{mg} / \mathrm{m}^{2}$ dożylnie (i.v., intravenous) w dniu -7 . i w dniu 0., a następnie jednorazowa infuzja ${ }^{90} \mathrm{Y}$-ibritumomabu $\mathrm{w}$ dawce $14,8 \mathrm{MBq} / \mathrm{kg} \mathrm{mc}$. (0,4 mCI/kg mc.), tak aby całkowita dawka nie przekroczyła $1184 \mathrm{MBq}$ $(32 \mathrm{mCi})$. Szacowane 8-letnie PFS u chorych otrzymujących leczenie konsolidujące wynosiło $41 \%$, a u chorych obserwowanych $-22 \%(\mathrm{p}<0,0001)$. Znamienną statystycznie poprawę w zakresie PFS obserwowano równiez $\mathrm{w}$ podgrupach chorych, którzy uzyskali $\mathrm{CR} / \mathrm{CRu}(\mathrm{p}=0,008)$ oraz $\mathrm{PR}$ $(p<0,001)$ po leczeniu I linii. Nie obserwowano różnic między chorymi otrzymującymi konsolidację a chorymi obserwowanymi w zakresie 8-letniego OS (odpowiednio 84\% v. 81\%; $\mathrm{p}=0,045$ ). Częstość wtórnych zespołów mielodysplastycznych (MDS, myelodysplastic syndromes) i ostrych białaczek szpikowych (AML, acute myeloid leukemia) była statystycznie większa wśród chorych leczonych
${ }^{90}$ Y-ibritumomabem, a roczna zapadalność wynosiła 0,5\% w porównaniu z 0,07\% w grupie obserwacyjnej $(\mathrm{p}=0,042)$. Przy interpretacji wyników tego badania należy zwrócić uwagę na fakt, że jedynie $14,4 \%$ chorych (59/409) leczono immunochemioterapią w I linii, a $85,6 \%$ chorych otrzymywało różne formy chemioterapii bez rytuksymabu. Analiza PFS $\mathrm{w}$ podgrupie chorych leczonych immunochemioterapią nie wykazała istotnej różnicy w zakresie PFS między chorymi otrzymującymi konsolidację a chorymi obserwowanymi $(\mathrm{p}=0,36)$. Wydaje się więc, że obecnie, kiedy standardem leczenia I linii u chorych na FL jest immunochemioterapia, nie ma przekonujących dowodów na stosowanie ${ }^{90} \mathrm{Y}$-ibritumomabu jako leczenia konsolidującego $\mathrm{w}$ pierwszej remisji.

Wyniki badań $z$ ostatnich lat ugruntowały rolę leczenia podtrzymującego rytuksymabem u chorych na FL [5, 6]. W 2011 roku opublikowano wyniki randomizowanego, wieloośrodkowego badania PRIMA dotyczącego roli leczenia podtrzymującego rytuksymabem u chorych na FL [7]. Założeniem badania było wydłużenie mediany PFS o $45 \%$ u chorych leczonych podtrzymująco rytuksymabem i cel ten już osiągnięto przy pierwszej analizie etapowej. Do badania włączono 1217 chorych na FL $z$ dużą masą guza. Chorzy, zgodnie ze standardami w poszczególnych ośrodkach, otrzymywali leczenie indukujące według schematu R-CHOP, R-COP lub R-FCM (rytuksymab, fludarabina, cyklofosfamid, mitoksantron). Tysiąc dziewiętnastu pacjentów, którzy osiągnęli CR lub PR po leczeniu indukującym, następnie poddano randomizacji do leczenia podtrzymującego rytuksymabem $\mathrm{w}$ dawce $375 \mathrm{mg} / \mathrm{m}^{2}$ we wlewie dożylnym co 2 miesiące przez 2 lata (505 chorych) lub do grupy obserwacyjnej (513 chorych). Przy medianie obserwacji równiej 36 miesięcy 3-letnie PFS wynosiło 74,9\% w grupie leczonej rytuksymabem i 57,6\% w grupie obserwacyjnej ( $\mathrm{p}<0,0001)$. Wykazano również statystycznie istotne wydłużenie czasu do kolejnego leczenia przeciwchłoniakowego $(\mathrm{HR}=0,60$, $95 \%$ CI $0,47-0,76$; $p<0,0001)$ u chorych otrzymujących leczenie podtrzymujące $\mathrm{w}$ porównaniu $z$ chorymi obserwowanymi. Nie wykazano różnic w zakresie OS między obiema grupami chorych. Działania niepożądane III-IV stopnia według WHO obserwowano statystycznie częściej wśród chorych, którzy otrzymywali leczenie podtrzymujące niż w grupie obserwowanej $(\mathrm{p}=0,0026)$, w tym głównie infekcje w stopniu II-IV $(\mathrm{p}<0,0001)$. Na podstawie wyników badania PRIMA leczenie podtrzymujące rytuksymabem u chorych, którzy uzyskali CR lub PR po immunochemioterapii I linii, 
jest rekomendowane przez NCCN (kategoria 1) i Europejskie Towarzystwo Onkologii Medycznej (ESMO, European Society for Medical Oncology) (rekomendacja A). Należy pamiętać, aby każdorazowo u chorego leczonego rytuksymabem rozważyć wskazania do profilaktyki reaktywacji zakażenia wirusem zapalenia wątroby typu B (HBV, hepatitis $B$ virus).

W trakcie Konferencji ASH (American Society of Hematology) w 2011 roku zaprezentowano wyniki innego badania, w którym oceniano wartość leczenia podtrzymującego rytuksymabem [8]. Autorzy badania RESORT porównali skuteczność tego leczenia względem ponownej immunoterapii stosowanej dopiero w chwili nawrotu u 289 chorych na FL z małą masą guza, którzy po leczeniu I linii rytuksymabem $\mathrm{w}$ monoterapii osiągnęli odpowiedź. Parametrem do oceny tych dwóch podejść terapeutycznych był czas do następnego leczenia cytostatykami. Leczenie podtrzymujące pozwoliło znamiennie wydłużyć ten czas $(\mathrm{p}=0,03)$, ale za cenę 3-krotnie większego zużycia rytuksymabu. Ostatecznie leczenie podtrzymujące i ponowne leczenie rytuksymabem $\mathrm{w}$ chwili nawrotu uznano $\mathrm{w}$ tej populacji za równoważne [9].

Badaniem, które przyniosło odpowiedzi na pytanie o rolę rytuksymabu w leczeniu podtrzymującym po skutecznym leczeniu reindukującym, było badanie grupy EORTC (European Organisation for Research and Treatment of Cancer) opublikowane w 2010 roku [10]. Ogółem randomizacją objęto 465 chorych $z$ nawrotem lub progresją FL do grupy leczonej 6 cyklami CHOP lub 6 cyklami R-CHOP podawanymi co 21 dni. Chorzy $(n=334)$, którzy uzyskali CR lub PR po leczeniu reindukującym, zostali poddani drugiej randomizacji do grupy otrzymującej rytuksymab $\mathrm{w}$ leczeniu podtrzymującym według schematu $375 \mathrm{mg} / \mathrm{m}^{2}$ i.v. co 3 miesiące przez 2 lata lub do grupy obserwacyjnej. Dodanie rytuksymabu w leczeniu podtrzymującym wydłużało PFS o ponad 2,4 roku. Mediana PFS liczonego od drugiej randomizacji wynosiła 3,7 roku w grupie leczonej rytuksymabem i 1,3 roku w grupie obserwacyjnej ( $\mathrm{p}<0,001)$; różnice były istotne statystycznie zarówno w grupie leczonej CHOP $(\mathrm{p}<0,001)$, jak i R-CHOP $(\mathrm{p}=0,043)$. Korzyści $z$ dodania rytuksymabu w leczeniu podtrzymującym obserwowano zarówno u chorych, którzy uzyskali CR lub PR po leczeniu R-CHOP, jak i CHOP. Szacowane 5-letnie OS osiągnęło 74,3\% chorych otrzymujących rytuksymab w leczeniu podtrzymującym w porównaniu $z 64,7 \%$ chorych $z$ grupy obserwacyjnej $(p=0,07)$. Wydłużenie OS po dodaniu rytuksymabu w leczeniu podtrzymującym ob- serwowano zarówno u chorych, którzy w leczeniu reindukującym otrzymywali $\mathrm{CHOP}(\mathrm{p}=0,05)$, jak i w grupie leczonej R-CHOP $(\mathrm{p}=0,42)$, chociaż $\mathrm{w}$ tej ostatniej różnice nie osiągnęły znamienności statystycznej. Infekcje III-IV stopnia według WHO obserwowano częściej u chorych leczonych rytuksymabem niż w grupie obserwacyjnej $(9,7 \%$ v. 2,4\%; $\mathrm{p}=0,01)$. Większość infekcji dotyczyła górnych dróg oddechowych; nie stwierdzono większej częstości infekcji oportunistycznych czy zakażeń wirusowych. Należy podkreślić, że nie odnotowano zgonów związanych $z$ leczeniem podtrzymującym rytuksymabem.

Na Konferencji ASH w 2012 roku przedstawiono wyniki badania 2 . fazy, w którym zastosowano leczenie indukujące lenalidomidem w połączeniu $z$ rytuksymabem u 110 nieleczonych wcześniej chorych na chłoniaki indolentne o III lub IV stopniu zaawansowania według klasyfikacji Ann Arbor [11]. Lenalidomid stosowano w dawce $20 \mathrm{mg} /$ dobę w dniach 1.-21. każdego cyklu, zaś rytuksymab w dawce $375 \mathrm{mg} / \mathrm{m}^{2} 1$. dnia 28-dniowego cyklu przez 6 cykli. Zakładano możliwość przedłużenia terapii do 12 cykli u chorych, którzy odnosili korzyść kliniczną po 6 cyklach. Głównym punktem końcowym była ocena ORR, a cele drugorzędowe obejmowały między innymi ocenę PFS i OS. Stwierdzono, że ORR wyniósł 80\% (23\% CR i 57\% PR) u chorych na chłoniaka $z$ małych limfocytów (SLL, small lymphocytic lymphoma), 89\% (67\% CR i $22 \%$ PR) u chorych na chłoniaka strefy brzeżnej (MZL, marginal zone lymphoma) oraz 98\% (87\% CR i $11 \%$ PR) u chorych na FL. Ponadto, badając odpowiedź molekularną u chorych na FL, stwierdzono, że pogłębia się ona w czasie. Przed leczeniem wykazano obecność markerowej translokacji w komórkach krwi obwodowej lub szpiku kostnego u $41 \%$ chorych na FL; po 3 cyklach leczenia odsetek dodatnich wyników zmniejszył się do $11 \%$, a po 6 cyklach — do $5 \%$. Na podstawie uzyskanych wyników stwierdzono, że skojarzenie lenalidomidu $\mathrm{z}$ rytuksymabem w I linii leczenia chorych na chłoniaki indolentne stanowi wartościową opcję terapeutyczną [12].

Na Konferencji ASH w 2014 roku przedstawiono wyniki 8-letniej obserwacji randomizowanego badania 3 fazy, w którym porównywano skuteczność immunochemioterapii według schematu R-B (rytuksymab, bendamustyna) do R-F (rytuksymab, fludarabina) u pacjentów $z$ nawrotem chłoniaka indolentnego, w tym FL lub MCL [13]. Oceniono 219 chorych (114 w grupie leczonej R-B i $105 \mathrm{w}$ grupie leczonej R-F), których mediana wieku wynosiła 68 lat (zakres 38-87 lat). Randomizację rozpoczęto 
w 2003 roku, a w 2006 roku wprowadzono poprawkę do protokołu polegającą na możliwości podawania leczenia podtrzymującego rytuksymabem chorym, którzy uzyskali CR lub PR po leczeniu indukującym. Leczenie podtrzymujące otrzymało łącznie 40 chorych. Wśród chorych leczonych R-B odsetek ORR był statystycznie większy, w tym również $\mathrm{CR}$, w porównaniu $\mathrm{z}$ chorymi leczonymi RF (ORR 83,5\% v. 52,5\%, p < 0,0001; CR 38,5\% v. $16,2 \%, \mathrm{p}=0,0004)$. Przy medianie obserwacji wynoszącej 96 miesięcy mediana PFS i mediana OS były istotnie dłuższe $\mathrm{w}$ grupie leczonej R-B niż w leczonej R-F (PFS 34 v. 12 miesięcy, p < 0,0001; OS $110 v .49$ miesięcy, $\mathrm{p}=0,01)$. W grupie 40 chorych, którzy otrzymali leczenie podtrzymujące, wykazano większe prawdopodobieństwo PFS ( $<<0,0001)$ i OS ( $=0,0003)$ w porównaniu $z$ chorymi obserwowanymi, ale analizowana grupa nie była liczna, a chorzy do leczenia podtrzymującego lub obserwacji nie byli poddawani randomizacji, dlatego na podstawie powyższych wyników nie można sformułować ostatecznego wniosku. Toksyczność hematologiczna leczenia w obu grupach była porównywalna, podobnie częstość ciężkich działań niepożądanych i wtórnych nowotworów. Wyniki powyższego badania wskazują, że u chorych $z$ nawrotem chłoniaka indolentnego lub MCL schemat R-B jest bardziej skuteczny w odniesieniu do ORR, CR, PFS, OS niż schemat R-F.

Kolejnym ważnym doniesieniem dotyczącym leczenia pacjentów $z$ opornymi chłoniakami indolentnymi było badania 2 . fazy $z$ zastosowaniem idelalisibu - doustnego, selektywnego inhibitora kinazy $\delta 3$-fosfatydyloinozytolu (PI3K $\delta$ ) prezentowane podczas konferencji ASH w 2013 roku [6]. U 125 chorych na indolentne NHL opornych na wcześniejszą chemioterapię rytuksymabem i lekami alkilującymi stosowano idelalisib w dawce $150 \mathrm{mg} 2 \mathrm{razy} /$ dobę do czasu stwierdzenia progresji lub toksyczności. Mediana czasu leczenia idelalisibem wynosiła 6,6 miesiąca. Odsetek ORR wynosił $57 \%$, w tym $6 \% \mathrm{CR}$ z medianą czasu trwania odpowiedzi 12,5 miesiąca. Medianę PFS oceniono na 11 miesięcy. Wśród najczęstszych działań niepożądanych III-IV stopnia według WHO obserwowano neutropenię (27\% chorych), biegunkę (13\%), wzrost aktywności aminotransferaz (13\%) oraz zapalenie płuc (7\%). Wyniki powyższego badania wskazują, że idelalisib w monoterapii jest skutecznym lekiem u pacjentów $z$ opornymi chłoniakami indolentnymi i cechuje go akceptowalny profil bezpieczeństwa [14].

\section{Makroglobulinemia Waldenströma}

W ostatnich latach zidentyfikowano mutację pojedynczego nukleotydu w genie MYD88 (myeloid differentiation primary response) zlokalizowanym na chromosomie 3p22.2. Mutacja MYD88 L265P występuje u ponad $90 \%$ chorych na makroglobulinemię Waldenströma (WM, Waldenström macroglobulinemia) i może sprzyjać rozwojowi chłoniaka poprzez stymulację wewnątrzkomórkowych szlaków sygnałowych, w które są zaangażowane kinaza tyrozynowa Brutona (BTK, Bruton tyrosine kinase) i konstytutywna aktywacja czynnika jądrowego $\kappa \mathrm{B}(\mathrm{NF} \kappa \mathrm{B}$, nuclear factor $\kappa B)$ [15]. Duża częstość występowania tej mutacji — zarówno u chorych na WM, jak i u ponad $50 \%$ pacjentów z gammapatią IgM o nieustalonym znaczeniu (MGUS, monoclonal gammapathy of undetermined significance) - może świadczyć o tym, że mutacja MYD88 L265P jest raczej jednym ze zdarzeń inicjujących, a nie zdarzeniem transformującym bezpośrednio związanym $z$ rozwojem nowotworu. Mutacji MYD88 L265P nie obserwowano u chorych na szpiczaka plazmocytowego (PCM, plasma cell myeloma), stwierdzano ją natomiast u około 7\% chorych na MZL. Ponadto niską ekspresję genu MYD88 L265P wykazano u $14-29 \%$ pacjentów $z$ chłoniakiem rozlanym $z$ dużych komórek B (DLBCL, diffuse large $B$-cell lymphoma) (podtyp ABC [activated B-cell]), 9\% chorych na chłoniaka typu MALT (mucosa-associated lymphoid tissue) oraz u 3\% pacjentów z CLL. Dodatkowo u $1 / 3$ chorych na WM zidentyfikowano dodatkowe mutacje w genie $C X C R 4$ dotyczące C-końcowego fragmentu receptora dla chemokiny CXC4 (receptor 4 dla chemokiny czynnika pochodzącego $z$ komórek zrębu [SDF-1, stromal cell-derived factor 1]). Wykazano, że rodzaj mutacji w genach MYD88 i CXCR4 może mieć również implikacje kliniczne.

Na Konferencji ASH w 2013 roku przedstawiono wyniki badania 2 . fazy, w którym stosowano ibrutynib w dawce $420 \mathrm{mg} /$ dobę u 63 chorych $z$ nawrotem lub opornością WM [6]. Oceniono nie tylko bezpieczeństwo i skuteczność ibrutynibu, ale również wpływ mutacji L265P MYD88 i WHIM-like CXCR4 na wyniki leczenia. Obserwowano istotną statystycznie poprawę w zakresie stężeń hemoglobiny $(\mathrm{Hb})$ i białka monoklonalnego IgM oraz zmniejszenia nacieku w szpiku kostnym $(\mathrm{p}<0,01$ dla wszystkich porównań). Mediana czasu do uzyskania minimalnej odpowiedzi wynosiła tylko 4 tygodnie. Stwierdzono, że ORR był równy $90,5 \%$, w tym było $73 \%$ większych odpowiedzi. Chorzy z obecnością 
mutacji L265P MYD88 częściej uzyskiwali odpowiedź na leczenie niż chorzy bez tej mutacji. $Z$ kolei chorzy z mutacją WHIM-like w genie CXCR4 rzadziej uzyskiwali bardzo dobrą odpowiedź częściową (VGPR, very good partial response) i PR niz chorzy z dzikim allelem, co potwierdza wyniki badań in vitro, w których obecność mutacji WHIM-like i większa ekspresja CXCR4 zmniejsza wrażliwość komórek WM na ibrutynib. Szacowane 2-letnie PFS i OS osiągnęło odpowiednio $69,1 \%$ oraz $95,2 \%$ chorych. Wśród objawów niepożądanych najczęściej obserwowano neutropenię (22\%) i małopłytkowość (14\%) [16].

Według aktualnych rekomendacji International Workshop on Waldenstrom's Macroglobulinemia (IWWM) [17], podobnie jak w rekomendacjach poprzednich, w I linii leczenia powinien być stosowany schemat RCD (rytuksymab, deksametazon, cyklofosfamid). Nie zaleca się już schematu R-CHOP jako leczenia pierwszego wyboru. Zamiast R-CHOP rekomenduje się schemat R-B, w szczególności $u$ chorych $z$ dużą masą guza. Powyższe rekomendacje dotyczące przewagi immunochemioterapii R-B nad R-CHOP opierają się na wynikach wcześniej cytowanego badania StiL, w którym wśród 549 objętych randomizacją chorych było 41 pacjentów z WM [3]. Przy medianie obserwacji równej 45 miesięcy u chorych na WM mediana PFS w grupie leczonej R-B wynosiła 69,5 miesiąca, a w grupie leczonej R-CHOP $-28,1$ miesiąca $(\mathrm{p}=0,0033)$.

\section{Chłoniak z komórek płaszcza}

Najważniejszym doniesieniem $z$ ostatnich lat badaczy z European Mantle Cell Lymphoma Network, przedstawianym na konferencjach ASH w 2010 i 2012 roku, było badanie służące porównaniu wyników leczenia indukującego 6 cyklami R-CHOP $z$ następczą radiochemioterapią mieloablacyjną (napromienianie całego ciała [TBI, total body irradiation] dawką $12 \mathrm{~Gy}, 2 \times 60 \mathrm{mg} / \mathrm{kg} \mathrm{mc}$. cyklofosfamidu) i przeszczepieniem autologicznych krwiotwórczych komórek macierzystych (auto-HSCT, autologous hematopoietic stem cells transplantation) (grupa kontrolna A) ze stosowaniem naprzemiennych cykli $3 \times \mathrm{CHOP}$ i $3 \times$ DHAP (deksametazon, arabinozyd cytozyny [Ara-C], cisplatyna) $z$ rytuksymabem, $z$ następczym schematem mieloablacyjnym $z$ wysokodawkowanym Ara-C (TBI w dawce $10 \mathrm{~Gy}$, Ara-C $4 \times 1,5 \mathrm{~g} / \mathrm{m}^{2}$, melfalan $140 \mathrm{mg} / \mathrm{m}^{2}$ ) i auto-HSCT (grupa eksperymentalna B) [5, 11]. Randomizacją objęto 497 chorych na MCL w wieku do 65 lat, w stadium zaawansowania II-IV. Częstość CR była większa w grupie chorych leczonych R-CHOP/R-DHAP niż $\mathrm{w}$ grupie pacjentów otrzymujących R-CHOP ( $36 \%$ v. $25 \% ; \mathrm{p}=0,012$ ). Podobnie dłuższy był czas trwania remisji ( $84 v .49$ miesięcy; $\mathrm{p}=0,0001$ ) oraz znamiennie dłuższa była mediana czasu do niepowodzenia leczenia (TTF, time-to-treatment failure) $\mathrm{w}$ grupie R-CHOP/R-DHAP $\mathrm{w}$ porównaniu $\mathrm{z}$ R-CHOP ( $\mathrm{p}=0,038)$. Po 36 miesiącach TTF, który definiowano jako stabilizację po indukcji, progresję i zgon niezależnie od przyczyny, osiągnęło $77 \%$ $\mathrm{w}$ grupie R-CHOP/R-DHAP w porównaniu z 60\% w grupie leczonej R-CHOP. Po 53-miesięcznej medianie obserwacji chorzy leczeni R-DHAP/R-CHOP osiągnęli znamiennie dłuższe OS $(\mathrm{p}=0,048)$ i korzyść ta odnosiła się do wszystkich podgrup ryzyka według MIPI (Mantle cell lymphoma International Prognostic Index). Analiza toksyczności wykazała częstsze występowanie działań niepożądanych $\mathrm{w}$ grupie leczonej R-DHAP/R-CHOP, w tym hematologicznych (leukopenia, neutropenia, niedokrwistość, małopłytkowość, gorączka neutropeniczna) i pozahematologicznych (wzrost stężenia kreatyniny, osłabienie, nudności, wymioty, zmniejszenie masy ciała). Natomiast w grupie leczonej R-CHOP istotnie częściej stwierdzano zaparcia i toksyczność wątrobową. Na podstawie powyższego badania protokół R-DHAP/R-CHOP jest rekomendowany jako standardowe leczenie I linii u mających mniej niż 65 lat chorych na MCL.

Na Konferencji ASH w 2011 roku przedstawiono wyniki randomizowanego badania grupy European MCL Network, w którym porównano skuteczność schematów R-FC (rytuksymab, fludarabina, cyklofosfamid) i R-CHOP (1. randomizacja) oraz leczenie podtrzymujące rytuksymabem $z$ leczeniem interferonem alfa (IFN $\alpha$ ) (2. randomizacja) $\mathrm{w}$ terapii I linii u 560 chorych na MCL powyżej 65. roku życia [8]. Wykazano, że choć odsetki uzyskiwanych CR były porównywalne, to progresję choroby częściej obserwowano w grupie leczonej $\mathrm{R}-\mathrm{FC}$ niż R-CHOP (14\% v. 5\%). Czas przeżycia chorych otrzymujących R-FC był istotnie krótszy niż chorych leczonych R-CHOP (4-letnie OS 47\% v. $62 \% ; \mathrm{p}=0,005)$ i więcej chorych leczonych R-FC zmarło w trakcie pierwszej remisji (10\% i $4 \%)$. Okres remisji był znamiennie dłuższy u chorych otrzymujących leczenie podtrzymujące rytuksymabem niż u przyjmujących IFN $\alpha$. Po 4 latach obserwacji $58 \%$ chorych leczonych rytuksymabem i $29 \%$ leczonych IFN $\alpha$ pozostawało w remisji $(\mathrm{p}=0,01)$. W grupie chorych, którzy uzyskali odpowiedź na leczenie indukujące R-CHOP, leczenie podtrzymujące rytuksymabem znamiennie wydłużało przeżycie w porównaniu $z$ leczeniem IFN $\alpha$ (4-letnie OS 87\% 
i $63 \%$; p = 0,005). Toksyczność hematologiczną częściej obserwowano w grupie leczonej R-FC niż R-CHOP, ale częstość infekcji III-IV stopnia według WHO była porównywalna (17\% v. 14\%) [18]. $\mathrm{Na}$ podstawie powyższego badania $\mathrm{u}$ chorych na MCL powyżej 65. roku życia zalecanym leczeniem indukującym jest 6 cykli R-CHOP $z$ następczym leczeniem podtrzymującym rytuksymabem.

Alternatywną immunochemioterapią indukującą remisję u chorych w wieku powyżej 60 lat, szczególnie tych obciążonych chorobami układu sercowo-naczyniowego lub w stanie ogólnym według ECOG powyżej 1, jest schemat R-B porównywany prospektywnie $z$ leczeniem R-CHOP $\mathrm{w}$ badaniu grupy STiL [3]. Przy medianie obserwacji wynoszącej 45 miesięcy w przypadku 94 chorych na MCL mediana PFS w grupie R-B wynosiła 35,4 miesiąca, a w grupie R-CHOP - 22,1 miesiąca $(\mathrm{p}=0,004)$. Wyniki badania BRIGHT, w którym chorych na MCL lub chłoniaki indolentne poddano randomizacji do leczenia indukującego według schematu R-B lub R-CHOP/R-CVP, potwierdziły przewage pierwszego schematu u chorych na MCL w odniesieniu do częstości uzyskiwanych CR $(\mathrm{p}=0,018)[11,19]$.

W tym roku opublikowano również wyniki randomizowanego badania 3. fazy (LYM-3002), w którym porównano leczenie indukujące 6-8 cyklami R-CHOP-21 z VR-CAP (R-CHOP, ale zamiast winkrystyny podawano bortezomib $\mathrm{w}$ dawce $1,3 \mathrm{mg} / \mathrm{m}^{2} \mathrm{w}$ dniach 1., 4., 8. i 11. każdego cyklu). Do badania włączono 487 pacjentów $z$ nowo rozpoznanym MCL niekwalifikujących się do auto-HSCT. U chorych leczonych VR-CAP obserwowano większy odsetek uzyskiwanych CR (53\% v. $42 \%)$ oraz dłuższą medianę czasu trwania CR $(42,1$ v. 18 miesięcy) niż w grupie leczonej R-CHOP. Przy 40-miesięcznej medianie obserwacji mediana PFS była istotnie dłuższa u chorych leczonych VR-CAP w porównaniu z R-CHOP (24,7 v. 14,4 miesięcy; $\mathrm{p}<0,001)$. Schemat VR-CAP jest bardziej aktywnym leczeniem niż R-CHOP u chorych niekwalifikujących się do auto-HSCT, ale jednocześnie wiąże się $z$ większą toksycznością hematologiczną, w tym szczególnie $z$ neutropenią i małopłytkowością [20].

Duże nadzieje na dalszą poprawę wyników leczenia u chorych na MCL wiąże się $z$ inhibitorami szlaku zależnego od receptora B-komórkowego (BCR, B-cell receptor), w tym zwłaszcza $z$ ibrutynibem. Na Konferencji ASH w 2012 roku przedstawiono wyniki leczenia ibrutynibem 111 pacjentów $z$ opornym bądź nawrotowym MCL (mediana wcześniejszych linii leczenia 3 , zakres 1-5) [11]. Ibrutynib stosowano w dawce $560 \mathrm{mg} /$ dobę w 28-dniowych cyklach do progresji lub nietolerancji. Uzyskano 68\% ORR, w tym 21\% CR i $47 \%$ PR. Zaobserwowano także pogłębianie się odpowiedzi w trakcie terapii; po czasie obserwacji 3,7 miesiąca stwierdzono odsetki CR $16 \%$ i PR $53 \%$, a po 14,7 miesiąca - CR 39\% i PR 35\%. Mediana czasu trwania odpowiedzi wyniosła 17,5 miesiąca, mediana PFS - 13,9 miesiąca, a mediana OS nie została osiagnnięta. Szacowane 18-miesięczne OS dotyczyło 58\% chorych. Toksyczność ibrutynibu obejmowała niepożądane działania hematologiczne i niehematologiczne, w tym: biegunkę, fatigue, nudności, infekcje układu oddechowego i duszność. Najczęstszymi działaniami niepożądanymi III-IV stopnia według WHO były zapalenie płuc, tkanki łącznej, układu moczowego, a nawet posocznica oraz występujące u około $2 \%$ chorych powikłania krwotoczne [21]. Ibrutynib w monoterapii stanowi więc skuteczną opcję leczenia chorych na nawrotowego lub opornego MCL.

\section{Chłoniaki rozlane z dużych komórek B}

Wcześniejsze badania niemieckiej grupy DSH-NHL (Deutsche Studiengruppe fur Hochmaligne Non-Hodgkin Lymphome) wskazywały na przewagę leczenia indukującego R-CHOP-14 nad R-CHOP-21 u chorych na DLBCL powyżej 60. roku życia lub młodszych $z$ grupy niskiego ryzyka według Międzynarodowego Wskaźnika Prognostycznego (IPI, International Prognostic Index). W kolejnych badaniach randomizowanych nie wykazano jednak takiej zależności. Na Konferencji ASH w 2013 roku przedstawiono wyniki metaanalizy, do której włączono 3749 chorych z 8 badań randomizowanych [6]. Wykazano, że ryzyko zgonu było o $26 \%$ niższe w grupie leczonej CHOP-14 w porównaniu z chorymi otrzymującymi CHOP-21, natomiast nie obserwowano różnicy istotnej statystycznie, porównując R-CHOP-14 i R-CHOP-21. Częstości zgonów związanych z leczeniem, ciężkich infekcji III-IV stopnia według WHO oraz gorączek neutropenicznych były porównywalne w obu grupach chorych. Wyniki tej analizy wskazują, że standardem leczenia indukującego nadal pozostaje R-CHOP-21.

Alternatywnym leczeniem indukującym jest immunochemioterapia według schematu R-ACVBP (rytuksymab, doksorubicyna, cyklofosfamid, windezyna, bleomycyna, prednizon) szeroko badana przez francuską grupę GELA (Groupe d'Etude des Lymphomes de l'Adulte) [5, 22]. W pracy opublikowanej w 2011 roku przedstawiono wyniki randomizowanego badania 3. fazy służącego porównaniu R-CHOP-21 ze schematem dose-intense R-ACVBP 
u chorych poniżej 60. roku życia z grupy niskiego ryzyka według IPI. Po 3 latach PFS wynosiło odpowiednio $73 \%$ i $87 \%$ przy istotnie większej toksyczności hematologicznej protokołu R-ACVBP ograniczającej jego zastosowanie do populacji chorych młodszych i w dobrym stanie ogólnym.

Właściwym kierunkiem działań zmierzających do poprawy skuteczności leczenia i minimalizacji objawów niepożądanych są próby dynamicznego modulowania dawki poszczególnych cytostatyków w kolejnych cyklach chemioterapii zależnie od ich farmakodynamiki i indywidualnej toksyczności leczenia. Przykładem może być protokół DA-EPOCH-R (dose-adjusted etopozyd, prednizon, winkrystyna, cyklofosfamid, doksorubicyna, rytuksymab), polegający na 96-godzinnym wlewie dożylnym etopozydu, winkrystyny i doksorubicyny wraz $z$ bolusem i.v. cyklofosfamidu i doustnie przyjmowanym prednizonem $\mathrm{w}$ taki sposób, aby zmiana jednorazowej dawki (do 20\%) etopozydu, doksorubicyny i cyklofosfamidu w danym cyklu spowodowała nadir neutrofilów we krwi obwodowej poniżej 0,5 G/1. W badaniu 2. fazy grupy CALGB (Cancer and Leukemia Group B) wykazano, że takie postępowanie przyczyniło się nie tylko do uzyskania lepszych wyników leczenia w całej badanej grupie (5-letnie PFS 81\% i OS 84\%) przy porównywalnej toksyczności w stosunku do wcześniej opublikowanych wyników odnośnie do schematu R-CHOP, ale również do poprawy wskaźników skuteczności obserwowanej w każdej badanej grupie wiekowej i prognostycznej według IPI. Protokół DA-EPOCH-R oceniano także w różnych podtypach molekularnych DLBCL, w których — podobnie do innych schematów leczenia - okazał się istotnie lepszy w podtypie GCB niż w non-GCB (5-letnie PFS $100 \%$ v. 67\%) [23]. Randomizowane porównanie skuteczności i toksyczności schematów DA-EPOCH-R z R-CHOP-21 u chorych na różne podtypy molekularne DLBCL jest przedmiotem obecnie prowadzonego badania klinicznego.

Standardem leczenia chorych na DLBCL o ograniczonym stopniu zaawansowania (I-II wg zmodyfikowanej w Lugano klasyfikacji z Ann Arbor, bez bulky tumor) jest zastosowanie $2-4$ cykli immunochemioterapii według schematu R-CHOP-21 oraz uzupełniającej IF-RT w dawce 35-40 Gy. Stosowanie IF-RT u takich chorych zmienią, być może, wyniki randomizowanego badania 3 . fazy francuskiej grupy LYSA (Lymphoma Study Association) przedstawione na konferencji ASH w 2014 roku [13]. Do badania włączono 313 chorych na DLBCL w stadium ograniczonym, bez bulky tumor, którzy byli stratyfikowani według IPI do grup z IPI wyno- szącym 0 i IPI równym co najmniej 1 . Pacjenci z IPI 0 otrzymywali 4 cykle R-CHOP, a chorzy $z$ IPI 1 lub więcej - 6 cykli R-CHOP. Pacjentów, u których wynik badania PET był negatywny, poddawano randomizacji do uzupełniającej IF-RT lub do grupy obserwowanej. Chorzy, którzy po 4 cyklach R-CHOP uzyskali PR w badaniu PET-CT, otrzymywali jeszcze 2 dodatkowe cykle R-CHOP i obligatoryjnie IF-RT. Po zakończeniu leczenia nie obserwowano różnic pod względem częstości uzyskiwanych CR w grupach leczonych R-CHOP i R-CHOP + IF-RT (93\% v. 95\%). Spośród 43 chorych, którzy osiągnęli PR po 4 cyklach R-CHOP, u 40 (93\%) odnotowano CR. Przy 51-miesięcznej medianie obserwacji nie stwierdzono różnic statystycznych między chorymi $z$ grup R-CHOP i R-CHOP + IF-RT w zakresie EFS (5-letni EFS osiągnęło 87\% v. 91\% chorych; $\mathrm{p}=0,1)$ i OS (5-letni OS osiągnęło $90 \%$ v. $95 \%$ chorych; $\mathrm{p}=0,3)$. Wyniki powyższego badania wskazują, że chorzy na DLBCL w stadium ograniczonym i bez masy bulky, którzy po 4 lub 6 cyklach R-CHOP osiaggają CR metaboliczną, nie odnoszą korzyści z uzupełniającej IF-RT. Wydaje się, że procedura IF-RT powinna być zarezerwowana dla chorych uzyskujących PR po R-CHOP, a dodanie u nich 2 cykli R-CHOP i IF-RT prowadzi do podobnych wyników, jak u chorych, którzy osiągają CR po leczeniu indukującym.

Wyniki badań profilu ekspresji genów (GEP, gene expression profiling) wykazały, że istnieją co najmniej 3 podgrupy molekularne DLBCL, $\mathrm{w}$ tym GCB (germinal center B-cell like), $\mathrm{ABC}$ i typ 3 . Udowodniono także, że mechanizmy molekularne prowadzące do podtrzymania potencjału proliferacyjnego $\mathrm{w}$ tych podgrupach są różne. Chłoniaki typu GCB (GCB-DLBCL) charakteryzuje sygnatura genowa i fenotypowa prawidłowych limfocytów B ośrodka rozmnażania grudki chłonnej, w tym wysoka ekspresja BCL6 i CD10. Czynnik transkrypcyjny BCL6 jest kluczowym regulatorem potencjału proliferacyjnego komórek chłoniakowych GCB-DLBCL, którego zwiększona ekspresja zależy od translokacji genu w obszar regulatorowy genów dla immunoglobulin lub/i mutacji somatycznych. Podtyp ABC-DLBCL charakteryzują zahamowanie ekspresji białek uczestniczących $\mathrm{w}$ formowaniu grudek chłonnych oraz zwiększona ekspresja genów i białek zaangażowanych w proces aktywacji limfocytów B przed ich ostatecznym zróżnicowaniem plazmatycznokomórkowym, takich jak kinaza PIM-1, IRF4/MUM1, BCL2. Kluczowym czynnikiem transkrypcyjnym odpowiedzialnym za potencjał proliferacyjny komórek chłoniakowych $\mathrm{ABC}-\mathrm{DLBCL}$ jest $\mathrm{NF} \kappa \mathrm{B}$. Biorąc pod uwagę wszyst- 
kich chorych na DLBCL, odsetki 5-letnich przeżyć w przypadku korzystnego typu GCB oraz niekorzystnego $\mathrm{ABC}$ wynoszą odpowiednio $62 \%$ i $26 \%$. Chociaż wprowadzenie rytuksymabu (R-CHOP) poprawiło wyniki $\mathrm{w}$ obu podgrupach molekularnych w stosunku do leczenia za pomocą CHOP, to jednak rokowanie chorych $z$ profilem ekspresji genów o typie ABC-DLBCL pozostało istotnie gorsze niż z GCB-DLBCL. Obecnie największe nadzieje na poprawę wyników leczenia w poszczególnych podgrupach molekularnych DLBCL wiąże się $\mathrm{z}$ ingerencją $\mathrm{w}$ komórkowe szlaki sygnałowe zlokalizowane powyżej aktywacji $\mathrm{NF} \kappa \mathrm{B}$, zależne od kaskady przekazywania sygnału BCR. Molekularną przesłanką do takich ingerencji jest obecność tonicznej aktywacji BCR i/lub mutacji aktywujących w jego sygnalozomie (CD79, CARD11 i MYD88) w komórkach DLBCL $\mathrm{z}$ wysoką konstytutywną aktywnością $\mathrm{NF} \kappa \mathrm{B}$. Jednym $z$ takich celów terapeutycznych jest BTK hamowana za pomocą jej selektywnego inhibitora - ibrutynibu.

W badaniu klinicznym 2. fazy u 70 chorych na nawrotowego lub opornego DLBCL stosowano ibrutynib w dawce $560 \mathrm{mg} /$ dobę [11]. Łączny odsetek odpowiedzi wyniósł $40 \%$ u chorych na ABC-DLBCL (8\% CR i 32\% PR) w porównaniu z 5\% (CR 0\% i PR 5\%) w grupie GCB-DLBCL $(\mathrm{p}=0,007)$, a OS - odpowiednio 9,7 w porównaniu z 3,3 miesiąca $(\mathrm{p}=0,099)$. Wyniki tego badania mogą wskazywać na istotną rolę szlaku sygnałowego zależnego od $\mathrm{BCR}$ w podgrupie molekularnej ABC-DLBCL, a nie w GCB-DLBCL. Ponadto wykazano, że czynnikiem predykcyjnym odpowiedzi na leczenie ibrutynibem jest obecność mutacji aktywujących w niektórych białkach uczestniczących w przekazywaniu sygnału $z$ BCR do wnętrza komórki (CD79B i MYD88), choć nie dotyczy ich wszystkich (CARD11).

Potencjalną skuteczność w leczeniu chorych na ABC-DLBCL wykazują też inne inhibitory szlaku sygnałowego zależnego od $\mathrm{BCR}$, w tym kinazy SYK (fostamatynib), kinazy białkowej $\mathrm{C} \beta$ (enzastauryna), szlaku PI3K/AKT/mTOR (temsirolimus i ewerolimus) i PI3K $\delta$ (idelalisib). W 2014 roku opublikowano interesujące wyniki badania fazy $1 \mathrm{~b}$, w którym ibrutynib stosowano w połączeniu $z$ R-CHOP-21 w leczeniu indukującym u chorych na DLBCL $[6,24]$. Pierwszorzędowym celem badania było określenie dawki leku, a drugorzędowymi - ocena bezpieczeństwa, ORR oraz farmakokinetyki i farmakodynamiki ibrutynibu. W pierwszej części badania u 17 chorych na DLBCL, FL i MCL określono optymalną dawkę ibrutynibu. Ze względu na fakt, że nie osiągnięto maksymalnej tolerowanej dawki (MTD, maximum tolerated dose), w drugiej części badania u 16 chorych na DLBCL zastosowano ibrutynib w dawce $560 \mathrm{mg} /$ dobę w połączeniu z R-CHOP-21. Nie obserwowano wpływu R-CHOP na farmoakokinetykę ibrutynibu ani wpływu ibrutynibu na farmakokinetykę winkrystyny (substrat CYP3A4). Wśród zdarzeń niepożądanych w III-IV stopniu według WHO dominowały neutropenia (73\%), małopłytkowość (21\%) i niedokrwistość (18\%) oraz gorączka neutropeniczna (18\%). Odpowiedź na leczenie oceniono u 18 chorych na DLBCL. Łączny odsetek odpowiedzi wynosił $100 \%$, w tym $91 \%$ CR i 9\% PR. Wszyscy chorzy z podtypem $A B C-D L B C L$ uzyskali $C R$, natomiast w grupie GCB-DLBCL osiągnięto 71\% CR. Wyniki powyższego badania wskazują, że ibrutynib w połączeniu z R-CHOP może poprawić wyniki leczenia indukującego u chorych na DLBCL, ale konieczne jest badanie 3. fazy, aby potwierdzić te obserwacje.

$\mathrm{U}$ chorych na $\mathrm{ABC}-\mathrm{DLBCL}$ testuje się także inne strategie, $w$ tym leki immunomodulujące, takie jak lenalidomid, które działają poniżej kaskady szlaków zależnych od czynnika transkrypcyjnego $\mathrm{NF} \kappa \mathrm{B}$. Lenalidomid stosowany $\mathrm{w}$ monoterapii $\mathrm{u}$ chorych na nawrotowy lub oporny DLBCL pozwala na uzyskanie $53 \%$ ORR w grupie non-GCB w porównaniu z $9 \%$ u pacjentów z podtypem GCB [25]. Wiadomo, że prawie $40 \%$ starszych chorych ma nawrót lub rozwija się u nich oporność na leczenie indukujące R-CHOP-21. W 2014 roku opublikowano wyniki badania 2. fazy (REAL07), w którym u 49 osób w wieku 60-80 lat chorych na DLBCL lub FL 3B w leczeniu I linii zastosowano lenalidomid w połączeniu $z$ R-CHOP-21 (LR-CHOP) [6, 26]. Lenalidomid stosowano w dawce $15 \mathrm{mg}$ w 1.-14. dniu 21-dniowych cykli, a R-CHOP w dawkach standardowych. Łączny odsetek odpowiedzi wynosił 92\% (86\% CR, 6\% PR). Przy 28-miesięcznej medianie obserwacji szacowane 2-letnie PFS wynosiło $80 \%$, a 2-letnie OS - $92 \%$. Nie obserwowano różnic w odniesieniu do ORR, PFS i OS w podgrupach GCB i non-GCB. Najczęściej obserwowane objawy niepożądane III-IV stopnia według WHO obejmowały neutropenię (31\%) i małopłytkowość (13\%). Wyniki powyższego badania wskazują, że schemat LR-CHOP jest skutecznym i bezpiecznym leczeniem indukującym u starszych chorych na DLBCL. Konieczne są dalsze badania 3. fazy służące porównaniu schematów LR-CHOP-21 z R-CHOP-21. W 2015 roku opublikowano wyniki badania 2 . fazy, w którym oceniono skuteczność LR-CHOP-21 u chorych na DLBCL w zależności od podtypu non-GCB i GCB [27]. Lenalidomid stosowano w dawce $25 \mathrm{mg} \mathrm{w}$ 1.- 
-10. dniu 21-dniowych cykli, a R-CHOP w dawkach standardowych. Łączny odsetek odpowiedzi wynosił 98\% (80\% CR, 18\% PR). Szacowane 2-letnie PFS osiagnęło 59\%, a 2-letnie OS 78\% chorych, przy czym nie obserwowano różnic w zależności od podtypu non-GCB czy GCB. Powyższe wyniki porównano $z$ wynikami w grupie kontrolnej liczącej 87 chorych na DLBCL leczonych według standardowego schematu R-CHOP-21, u których obserwowano różnice $\mathrm{w}$ odniesieniu do PFS i OS; 2-letnie PFS wynosiło $28 \%$ w porównaniu $\mathrm{z} 64 \%$ ( $\mathrm{p}<0,001$ ) odpowiednio dla podtypów non-GCB i GCB, a 2-letnie OS osiągnęło $46 \%$ w porównaniu z 78\% (p < 0,001) pacjentów odpowiednio $z$ podtypem non-GCB oraz GCB. Wyniki powyższego badania wskazują, że dodanie lenalidomidu do schematu R-CHOP-21 poprawia wyniki leczenia u chorych na DLBCL i zmniejsza negatywny wpływ podtypu non-GCB na odległe wyniki leczenia.

Należy podkreślić, że obecnie, poza protokołami badań klinicznych, nie ma różnic w postępowaniu terapeutycznym u chorych na DLBCL zależnie od podgrupy molekularnej czy immunohistochemicznej.

\section{Chłoniak pierwotny śródpiersia z dużych komórek B}

W chłoniaku pierwotnym śródpiersia $z$ dużych komórek B (PMBL, primary mediastinal large B-cell lymphoma) dotychczas nie ustalono optymalnego leczenia I linii. Na podstawie wyników badania MINT, w którym porównywano leczenie według schematu CHOP (lub podobnego) $z$ immunochemioterapią R-CHOP, w wielu ośrodkach standardem leczenia PMBL stał się protokół R-CHOP. Łącznie do badania MINT włączono 824 osoby poniżej 60. roku życia chore na DLBCL w II-IV stopniu zaawansowania lub w I stopniu ze zmianą masywną i z liczbą czynników IPI nie większą niż 1 . Chorzy na PMBL stanowili $11 \%(n=87)$ całej grupy pacjentów i ci, którzy w leczeniu indukującym otrzymywali immunochemioterapię R-CHOP-21 lub R-CHOEP (R-CHOP z etopozydem), częściej uzyskiwali CR ( $84 \%$ v. 50\%; p =0,03), dłuższe było u nich 3-letnie EFS (78\% v. 52\%; $\mathrm{p}=0,012)$ i podobne 3-letnie OS $(88,5 \%$ v. $78 \% ; \mathrm{p}=0,158)$ $\mathrm{w}$ porównaniu $\mathrm{z}$ chorymi leczonymi chemioterapią [28]. Przedmiotem kontrowersji pozostają rodzaj/intensywność stosowanej chemioterapii oraz rola uzupełniającej radioterapii, gdyż dotychczas nie przeprowadzono randomizowanych badań klinicznych, w których rozstrzygnięto by ten problem. W 2013 roku opublikowano wyniki prospektywnego badania 2 . fazy, w którym u 51 chorych na PMBL zastosowano schemat DA-EPOCH-R. Uzupełniającą radioterapię przewidziano jedynie dla chorych, którzy nie uzyskali CR. Pięcioletnie EFS osiągnęło 93\%, 5-letnie OS - 97\% chorych. Nie obserwowano kardiotoksyczności leczenia; nastąpił 1 zgon $z$ powodu AML. U 96\% pacjentów nie zastosowano uzupełniającej radioterapii. Wyniki tego badania wskazują, że intensyfikacja leczenia według schematu DA-EPOCH-R poprawia odległe wyniki leczenia i znosi konieczność uzupełniającej radioterapii, ale niezbędne są randomizowane badania $\mathrm{w}$ celu bezpośredniego porównania tego schematu leczenia ze schematem R-CHOP-21 [29].

\section{Chłoniaki T-komórkowe}

U chorych na chłoniaki z obwodowych komórek T (PTCL, peripheral T cell lymphoma) skuteczność leczenia I linii może poprawić dołączeniu etopozydu do standardowego schematu CHOP. W 7 różnych badaniach 2 . i 3 . fazy przeprowadzonych przez GHGNHLSG (German High-Grade non-Hodgkin Lymphoma Study Group) łącznie u 320 chorych na nowotwory $z$ dojrzałych komórek $\mathrm{T}$ i komórek naturalnej cytotoksyczności (NK, natural killer), w tym u 78 chorych na chłoniaka anaplastycznego $z$ dużych komórek (ALCL, anaplastic large cell lyphoma) ALK+, 113 ALCL ALK-, 70 z PTCL-NOS oraz 28 chorych na angioimmunoblastycznego chłoniaka T-komórkowego (AITL, angioimmunoblastic T-cell lymphoma), wykazano przewage schematu CHOEP u chorych poniżej 60. roku życia i z prawidłowymi wartościami dehydrogenazy mleczanowej (LDH, lactate dehydrogenase) dotyczącą PFS (75,4\% v. 51\%), ale bez wpływu na OS. Największą korzyść $z$ dołączenia etopozydu wykazano w grupie ALCL ALK + i choć podobny trend wykazano w odniesieniu do innych podtypów histopatologicznych, to znacząca nadreprezentacja tego rozpoznania wśród wszystkich leczonych chorych mogła wpływać na globalne wyniki analiz. W badaniach wykazano także, że dołączenie etopozydu wiązało się $z$ istotnym nasileniem toksyczności w grupie chorych w starszym wieku (> 60. rż.) [30].

Kolejną próbą poprawy wyników leczenia po początkowej odpowiedzi uzyskanej po 6 cyklach CHOEP, podawanych co 14 dni (CHOEP-14), była konsolidacja wysokodawkowaną chemioterapią według schematu BEAM (karmustyna, etopozyd, arabinozyd cytozyny, melfalan lub cyklofosfamid) wspomagana auto-HSCT. W badaniu 2. fazy grupy nordyckiej NLG (Nordic Lymphoma Group) po zastosowaniu takiego protokolu (etopozydu nie stosowano u chorych $>60$. rż.) uzyskano $82 \%$ 
ORR i 51\% CR. Należy zauważyć, że dobre wyniki leczenia uzyskano $\mathrm{w}$ grupie chorych $\mathrm{z}$ medianą wieku wynoszącą 57 lat, z których u ponad $70 \%$ występowała choroba wysokiego ryzyka według IPI ( $>1)$, a u ponad $80 \%$ - choroba zaawansowana w stopniu III-IV według klasyfikacji z Ann Arbor. Przy 60,5-miesięcznej medianie obserwacji 5-letnie PFS osiągnęło 44\% chorych, a 5-letnie OS - 51\%. W badaniu nie uczestniczyli chorzy z ALCL ALK+, a wyniki w pozostałych grupach były następujące (5-letnie PFS i OS): ALCL ALK- - 61\% i 70\%, PTCL-NOS - 38\% i $47 \%$ oraz AITL - $49 \%$ i $52 \%$ ). [31]. Wyniki tego badania skłaniają do wykorzystywania auto-HSCT w konsolidacji początkowej odpowiedzi, choć brakuje w tym zakresie badań randomizowanych.

Na Konferencji ASH w 2013 roku przedstawiono retrospektywną analizę, w której u 34 chorych na PTCL ( $z$ wyłączeniem ALCL ALK +) w leczeniu I linii stosowano naprzemiennie cykle GDP (gemcytabina, deksametazon i cisplatyna) i CHOP [6]. Mediana wieku chorych wynosiła 58 lat. W wyniku zastosowanego leczenia ORR wyniósł $82 \%$, w tym $62 \%$ CR. Po medianie czasu obserwacji wynoszącej 2,8 roku roczne OS osiagnęło 78\%, a 2-letnie OS - 64\%. Tolerancja GDP była dość dobra; nie odnotowano zgonów związanych $z$ zastosowanym leczeniem. Wśród charakterystycznych objawów niepożądanych obserwowano niewydolność nerek, ubytek słuchu i wysypkę. Wyniki tego badania wskazują, że leczenie według naprzemiennych schematów GDP/CHOP może obniżyć ryzyko rozwoju oporności na chemioterapię u chorych $z$ grupy wysokiego ryzyka PTCL.

Ograniczone możliwości udoskonalenia protokołów chemioterapii I linii, w tym nieudokumentowana w badaniach prospektywnych rola auto-HSCT w konsolidacji, skłoniła badaczy do poszukiwania innych rozwiązań i nowych leków. Pralatreksat należy do nowej generacji antagonistów kwasu foliowego zaburzających syntezę DNA przez odwracalne zahamowanie reduktazy dihydrofolianowej. W porównaniu z metotreksatem działa silniej i bardziej wybiórczo na komórki nowotworowe. W badaniach klinicznych 1 . i 2. fazy u wcześniej leczonych chorych na nawrotowe postaci PTCL-NOS, ALCL i AITL pralatreksat zastosowany $\mathrm{w}$ dawce $30 \mathrm{mg} / \mathrm{m}^{2} /$ tygodniowo przez 6 tygodni w 7-tygodniowych cyklach do czasu progresji choroby umożliwił uzyskanie $29 \%$ ORR, w tym $11 \%$ CR z 10,5-miesięczną medianą czasu trwania odpowiedzi [32]. Ze względu na toksyczność pralatreksatu (zapalenie błon śluzowych, nudności i małopłytkowość) jego jednoczasowe dołączenie do protokołów chemioterapii nie wydaje się możliwe, ale prowadzone jest badanie 3. fazy wykorzystujące jego potencjał w konsolidacji początkowej odpowiedzi uzyskanej za pomocą CHOP (NCT01420679).

Inną obiecującą grupą leków są inhibitory deacetylazy histonowej (HDAC, histone deacetylase), $\mathrm{w}$ tym zwłaszcza romidepsyna, której zastosowanie $\mathrm{w}$ monoterapii $\mathrm{w}$ dawce $14 \mathrm{mg} / \mathrm{m}^{2}$ (w dniach 1., 8. i 15. w cyklach co 28 dni do czasu progresji choroby) u chorych na nawrotowe PTCL, w tym PTCL-NOS, AITL i ALCL ALK-, umożliwiło uzyskanie $25 \%$ ORR, w tym $15 \%$ CR z 17-miesięczną medianą czasu trwania odpowiedzi $[5,33]$. Wyniki tych badań były podstawą podjęcia prób skojarzenia romidepsyny $z$ CHOP u wcześniej nieleczonych chorych, w tym w ramach randomizowanych badań klinicznych 3. fazy (NCT01796002) [34].

Lekiem, $z$ którym wiąże się największe nadzieje na poprawę wyników leczenia chorych na CD30+ nowotwory $\mathrm{z}$ dojrzałych komórek $\mathrm{T}$, jest brentuksymab vedotin $(\mathrm{BV})$ - przeciwciało monoklonalne anty-CD30 skoniugowane $z$ cząsteczką cytotoksyczną (monometyloaurystatyną E) o działaniu antytubulinowym, która po związaniu kompleksu $z$ receptorem przedostaje się do wnętrza komórki docelowej, powodując zatrzymanie jej cyklu podzialowego i śmierć. W badaniu 2. fazy u 58 chorych na nawrotową ( $62 \%$ pierwotna chemiooporność) postać ALCL (72\% ALCL ALK-) BV podawany w monoterapii w dawce $1,8 \mathrm{mg} / \mathrm{kg} \mathrm{mc}$. co 3 tygodnie (do 16 dawek) pozwolił na uzyskanie 86\% ORR (57\% CR), z medianą czasu trwania odpowiedzi wynoszącą 12,6 miesiąca. Najczęstszym objawem niepożądanym były przemijająca neuropatia $(41 \%)$ i cytopenie (neutropenia i małopłytkowość) $[8,35]$. Na Konferencji ASH w 2013 roku przedstawiono wyniki po 33,4-miesięcznej medianie obserwacji wskazujące, że mediana PFS u chorych leczonych BV wyniosła 14,6 miesiąca, natomiast mediany OS nie osiągnięto [6]. Trwa randomizowane badanie kliniczne 3. fazy w celu oceny skuteczności i toksyczności skojarzenia BV z CHP (cyklofosfamid, doksorubicyna, winkrystyna) w porównaniu $z$ CHOP u wcześniej nieleczonych chorych na CD30+ nowotwory $z$ dojrzałych komórek $T$ (ECHELON-2, NCT01777152) [11].

Na Konferencji ASH w 2013 roku przedstawiono również retrospektywną analizę dotyczącą skuteczności chemioterapii według schematu GDP stosowanej w leczeniu II linii u 51 chorych na PTCL [6]. Oceniono, że ORR wyniósł $80 \%$, $\mathrm{w}$ tym $47 \%$ CR. Po medianie czasu obserwacji wynoszącej 10,4 miesiąca 2-letnie PFS wyniosło $25 \%$, a OS $-43 \%$, bez różnic w odniesieniu do 
poszczególnych podtypów histopatologicznych PTCL. Transplantację krwiotwórczych komórek macierzystych (HSCT, hematopoietic stem cells transplantation) przeprowadzono u 26 chorych, w tym 15 auto-HSCT i 11 przeszczepień allogenicznych krwiotwórczych komórek macierzystych (allo-HSCT, allogeneic hematopoietic stem cells transplantation)) (2 niemieloablacyjne). Chorzy poddawani allo-HSCT częściej bywali pierwotnie oporni na leczenie $\mathrm{w}$ porównaniu $\mathrm{z}$ chorymi leczonymi auto-HSCT $(\mathrm{p}=0,045)$. Dwuletnie OS po HSCT wyniosło $53 \%$. U chorych niepoddawanych konsolidacji za pomocą HSCT mediana PFS po GDP wyniosła 4,4 miesiąca, a mediana OS - 6,8 miesiąca. Wyniki tego badania wskazują, że schemat GDP jest aktywny u chorych $z$ nawrotem PTCL oraz zwiększa szansę długotrwałego przeżycia, zwłaszcza u chorych poddawanych HSCT.

Na uwagę zasługują także inne metody leczenia, w tym polegające na zastosowaniu inhibitora ALK (krizotynib) w ALCL ALK+, HDAC (romidepsyna, belinostat) w AITL czy inhibitora szlaku kinazy Aurora A (alisertib). Inhibitory kinazy Aurora A działają przeciwnowotworowo poprzez zaburzanie procesu mitozy. W 2014 roku opublikowano wyniki badania 2 . fazy, w którym alisertib stosowano $\mathrm{w}$ dawce $50 \mathrm{mg}$ doustnie $2 \mathrm{razy} /$ dobę przez 7 dni w cyklach 21-dniowych u 48 chorych, w tym na DLBCL, MCL, PTCL, chłoniaka Burkitta (BL, Burkitt lymphoma). Mediana wieku wyniosła 68 lat, a mediana liczby wcześniejszych linii leczenia - 3 (zakres 1-11). Najczęstsze zdarzenia niepożądane 3. i 4. stopnia obejmowały neutropenię (63\%), w tym gorączkę neutropeniczną (15\%), małopłytkowość (31\%), zapalenie błony śluzowej jamy ustnej (15\%) i fatigue (6\%). Łączny odsetek odpowiedzi w całej grupie chorych wyniósł $27 \%$, w tym $14 \%$ u chorych na DLBCL, $23 \%$ u chorych na MCL, $40 \%$ u chorych na chłoniaki stransformowane, $100 \%$ u chorych na BL i $50 \%$ u chorych na PTCL $[8,36]$. Badanie kliniczne 3. fazy służące porównaniu w tych wskazaniach klinicznych alisertibu z gemcytabiną, pralatreksatem lub romidepsyną jest aktualnie realizowane (NCT01482962).

\section{Podsumowanie}

Najważniejsze osiągnięcia w diagnostyce i leczeniu chorych na chłoniaki wiązały się $z$ lepszym poznaniem molekularnych mechanizmów odpowiedzialnych za podtrzymanie proliferacyjnego potencjału tych nowotworów, a w konsekwencji $z$ opracowaniem i wprowadzeniem do leczenia inhibitorów wewnątrzkomórkowych szlaków syg- nałowych zależnych od kinazy Brutona (ibrutynib), PI3K $\delta$ (idelalisib) czy czynnika transkrypcyjnego $\mathrm{NF} \kappa \mathrm{B}$ (bortezomib, lenalidomid). Istotną rolę odegrała również intensyfikacja schematów leczenia I linii poprzez dołączenie zarówno klasycznych cytostatyków, jak i nowych leków o odmiennych mechanizmach działania oraz wprowadzenie leczenia poremisyjnego. Wymienione $\mathrm{w}$ pracy osiagniecia przyczyniły się nie tylko do zwiększenia częstości uzyskiwanych CR i PR, ale przede wszystkim wydłużyły PFS oraz OS leczonych chorych.

\section{Piśmiennictwo}

1. Friedberg J.W., Byrtek M., Link B.K. i wsp. Effectiveness of first-line management strategies for stage I follicular lymphoma: analysis of the National LymphoCare Study. J. Clin. Oncol. 2012; 30: 3368-3375.

2. Federico M., Luminari S., Dondi A. i wsp. R-CVP versus R-CHOP versus R-FM for the initial treatment of patients with advanced-stage follicular lymphoma: results of the FOLL05 trial conducted by the Fondazione Italiana Linfomi. J. Clin. Oncol. 2013; 31: 1506-1513.

3. Rummel M.J., Niederle N., Maschmeyer G. i wsp. Study group indolent Lymphomas (StiL). Bendamustine plus rituximab versus CHOP plus rituximab as first-line treatment for patients with indolent and mantle-cell lymphomas: an open-label, multicentre, randomised, phase 3 non-inferiority trial. Lancet 2013; 381 : 1203-1210.

4. Morschhauser F., Radford J., Van Hoof A. i wsp. ${ }^{90}$ Yttrium-ibritumomab tiuxetan consolidation of first remission in advanced-stage follicular non-Hodgkin lymphoma: updated results after a median follow-up of 7.3 years from the International, Randomized, Phase III First-Line Indolent trial. J. Clin. Oncol. 2013; 31: 1977-1983.

5. Warzocha K. Najważniejsze doniesienia z V Ogólnopolskiej Konferencji po ASH. Hematologia 2011; 2: 172-203.

6. Warzocha K. Najważniejsze doniesienia z VIII Ogólnopolskiej Konferencji po ASH. Hematologia 2014; 5: 40-80.

7. Salles G., Seymour J.F., Offner F. i wsp. Rituximab maintenance for 2 years in patients with high tumour burden follicular lymphoma responding to rituximab plus chemotherapy (PRIMA): a phase 3, randomised, controlled trial. Lancet 2011; 377: $42-51$.

8. Warzocha K. Najważniejsze doniesienia z VI Ogólnopolskiej Konferencji po ASH. Hematologia 2012; 3: 147-180.

9. Kahl B.S., Hong F., Williams M.E. i wsp. Rituximab extended schedule or re-treatment trial for low-tumor burden follicular lymphoma: eastern cooperative oncology group protocol e4402. J. Clin. Oncol. 2014; 32: 3096-3102.

10. van Oers M.H., Van Glabbeke M., Giurgea L. i wsp. Rituximab maintenance treatment of relapsed/resistant follicular non-Hodgkin's lymphoma: long-term outcome of the EORTC 20981 phase III randomized intergroup study. J. Clin. Oncol. 2010; 28: 2853-2858.

11. Warzocha K. Najważniejsze doniesienia $z$ VII Ogólnopolskiej Konferencji po ASH. Hematologia 2013; 4: 137-178.

12. Fowler N.H., Davis R.E., Rawal S. i wsp. Safety and activity of lenalidomide and rituximab in untreated indolent lymphoma: an open-label, phase 2 trial. Lancet Oncol. 2014; 15: 1311-1318. 
13. Warzocha K. Najważniejsze doniesienia z IX Ogólnopolskiej Konferencji po ASH. Hematologia 2015; 6: (2) [złożone do druku].

14. Gopal A.K., Kahl B.S., de Vos S. u wsp. PI3K $\delta$ inhibition by idelalisib in patients with relapsed indolent lymphoma. N. Engl. J. Med. 2014; 370: 1008-1018.

15. Treon S.P., Xu L., Yang G. i wsp. MYD88 L265P somatic mutation in Waldenström's macroglobulinemia. N. Engl. J. Med. 2012; 367: 826-833.

16. Treon S.P., Tripsas C.K., Meid K. i wsp. Ibrutinib in previously treated Waldenström's macroglobulinemia. N. Engl. J. Med. 2015; 372: 1430-1440.

17. Dimopoulos M.A., Kastritis E., Owen R.G. i wsp. Treatment recommendations for patients with Waldenström macroglobulinemia (WM) and related disorders: IWWM-7 consensus. Blood 2014; 124: 1404-1411.

18. Kluin-Nelemans H.C., Hoster E., Hermine O. i wsp. Treatment of older patients with mantle-cell lymphoma. N. Engl. J. Med. 2012; 367: 520-531.

19. Flinn I.W., van der Jagt R., Kahl B.S. i wsp. Randomized trial of bendamustine-rituximab or R-CHOP/R-CVP in first-line treatment of indolent NHL or MCL: the BRIGHT study. Blood 2014; 123: 2944-2952.

20. Robak T., Huang H., Jin J. i wsp. Bortezomib-based therapy for newly diagnosed mantle-cell lymphoma. N. Engl. J. Med. 2015; 372: 944-953.

21. Wang M.L., Rule S., Martin P. i wsp. Targeting BTK with ibrutinib in relapsed or refractory mantle-cell lymphoma. N. Engl. J. Med. 2013; 369: 507-516.

22. Rycher C., Coiffier B., Haioun C. i wsp. Intensified chemotherapy with ACVBP plus rituximab versus standard $\mathrm{CHOP}$ plus rituximab for the treatment of diffuse large B-cell lymphoma (LNH03-2B): an open label randomized phase 3 trial. Lancet 2011; 378: 1858-1867.

23. Wilson W.H., Jung S.H., Porcu P. i wsp. A Cancer and Leukemia Group B multi-center study on DA-EPOCH-rituximab in untreated diffuse large B-cell lymphoma with analysis of outcome by molecular subtype. Haematologica 2012; 97: 758-765.

24. Younes A., Thieblemont C., Morschhauser F. i wsp. Combination of ibrutinib with rituximab, cyclophosphamide, doxorubicin, vincristine, and prednisone (R-CHOP) for treatment-naive patients with CD20-positive B-cell non-Hodgkin lymphoma: a non-randomised, phase 1b study. Lancet Oncol. 2014; 15: 1019-1026.

25. Hernandez-Ilizaliturri FJ., Deeb G., Zinzani P.L. i wsp. Higher response to lenalidomide in relapsed/refractory diffuse large B cell lymphoma in nongerminal center B-cell-like than germinal center B-cell-like phenotype. Cancer 2011; 117: 5058-5066.
26. Vitolo U., Chiappella A., Franceschetti S. i wp. Lenalidomide plus R-CHOP21 in elderly patients with untreated diffuse large B-cell lymphoma: results of the REAL07 open-label, multicentre, phase 2 trial. Lancet Oncol. 2014; 15: 730-737.

27. Nowakowski G.S., LaPlant B., Macon W.R. i wsp. Lenalidomide combined with $\mathrm{R}-\mathrm{CHOP}$ overcomes negative prognostic impact of non-germinal center B-cell phenotype in newly diagnosed diffuse large B-Cell lymphoma: a phase II study. J. Clin. Oncol. 2015; 33: 251-257.

28. Rieger M., Osterborg A., Pettengell R. i wsp.; MabThera International Trial (MInT) Group. Primary mediastinal B-cell lymphoma treated with CHOP-like chemotherapy with or without rituximab: results of the Mabthera International Trial Group study. Ann. Oncol. 2011; 22: 664-670.

29. Dunleavy K., Pittaluga S., Maeda L.S. i wsp. Dose-adjusted EPOCH-rituximab therapy in primary mediastinal B-cell lymphoma. N. Engl. J. Med. 2013; 368: 1408-1416.

30. Schmitz N., Trümper L., Ziepert M. i wsp. Treatment and prognosis of mature T-cell and NK-cell lymphoma: an analysis of patients with T-cell lymphoma treated in studies of the German High-Grade Non-Hodgkin Lymphoma Study Group. Blood 2010; 116: 3418-3425.

31. d'Amore F., Relander T., Lauritzsen G.F. i wsp. Up-front autologous stemcell transplantation in peripheral T-cell lymphoma: NLG-T-01. J. Clin. Oncol. 2012; 30: 3093-3099.

32. O'Connor O.A., Pro B., Pinter-Brown L. i wsp. Pralatrexate in patients with relapsed or refractory peripheral T-cell lymphoma: results from the pivotal PROPEL study. J. Clin. Oncol. 2011; 29: 1182-1189.

33. Coiffier B., Pro B., Prince H.M. i wsp. Results from a pivotal, open-label, phase II study of romidepsin in relapsed or refractory peripheral T-cell lymphoma after prior systemic therapy. J. Clin. Oncol. 2012; 30: 631-636.

34. Dupuis J., Ghesquieres H., Tilly H. i wsp. A phase Ib/II trial of romidepsin in association with $\mathrm{CHOP}$ in patients with peripheral T-cell lymphoma (PTCL): The Ro-CHOP study. Hematol. Oncol. 2013; 31 (supl. 1): 136-142.

35. Pro B., Advani R., Brice P. i wsp. Brentuximab vedotin (SGN-35) in patients with relapsed or refractory systemic anaplastic large-cell lymphoma: results of a phase II study. J. Clin. Oncol. 2012; 30: 2190-2196.

36. Friedberg J.W., Mahadevan D., Cebula E. i wsp. Phase II study of alisertib, a selective eaurora A kinase inhibitor, in relapsed and refractory aggressive B- and T-cell non-Hodgkin lymphomas. J. Clin. Oncol. 2014; 32: 44-50. 